\title{
Pemberdayaan untuk Meningkatkan Kinerja Penyuluh Pertanian di Kabupaten Boyolali, Provinsi Jawa Tengah
}

\section{The Empowerment to Improve The Performance of Agricultural Extension Agent in Boyolali Regency, Central Java Province}

\author{
Musa F. Banunaek ${ }^{1}$, Suminah ${ }^{2}$, Ravik Karsidi ${ }^{3}$ \\ ${ }^{1}$ Mahasiswa Program Pascasarjana Universitas Sebelas Maret \\ ${ }^{2}$ Staf Pengajar pada Program Studi Ilmu Penyuluhan Pembangunan/Manajemen Pengembangan Masyarakat, dan Program \\ Studi PKLH, Program Pasca Sarjana UNS \\ ${ }^{3}$ Staf Pengajar pada Program Studi Ilmu Penyuluhan Pembangunan/Manajemen Pengembangan Masyarakat. Program Pasca
} Sarjana UNS

\begin{abstract}
This research aimed to find out the performance of agricultural extension agents (thereafter called agents), to analyze the effect of the agents' individual, psychological, organizational and work environment factors on their performance in undertaking their main duty, and to find the empowerment model to improve the performance of agricultural extension agent. Data analysis in this research was conducted using a multiple regression analysis. The result of research showed that the performance of agricultural extension agents, on average, belonged to high criteria with the score of $77.73 \%$, while the hypothesis testing obtained $t$ stoin value of 1355 and $t_{\text {table }}$ of 2.01 so that $\left(t_{\text {statistic }}>t_{\text {table }}\right)$ meaning that the agents' individual, psychological, organizational and work environment factors simultaneously affected their performance. The factors exerting positive and significant effect on the performance were individual (experience), psychological (the agents' perception on their profession, attitude, and motivation), organizational (reward of the agents), and work environment (number of assisted farmers and interaction between the agents and the assisted farmers) factors, while the one exerting negative effect was the agents' area width. This research found the empowerment model to improve the agents' performance by means of considering the agents' individual, psychological, organizational and work environment factors.
\end{abstract}

Keywords: performance of agricultural extension agent, individual, psychological, organization, work environment

\begin{abstract}
Abstrak
Penelitian ini bertujuan untuk: Mengetahui tingkat kinerja (performance) penyuluh pertanian, menganalisis pengaruh faktor individu penyuluh, faktor psikologi penyuluh, faktor organisasi penyuluh dan faktor lingkungan kerja penyuluh terhadap kinerja penyuluh pertanian dalam melaksanakan tugas pokoknya dan menemukan model pemberdayaan untuk meningkatkan kinerja penyuluh pertanian. Analisis data dalam penelitian ini menggunakan analisis regresi berganda. Hasil penelitian menunjukan bahwa kinerja penyuluh pertanian rata-rata termasuk dalam kriteria tinggi yaitu sebesar 77,73 persen sedangkan uji hipotesa diperoleh nilai $t_{\text {hitung }}$ sebesar 1355 dan $t_{\text {tabel }}$ 2,01 sehingga $\left(t_{\text {hitung }}>t_{\text {tabel }}\right.$ ) yang di artikan bahwa secara bersama-sama faktor individu penyuluh, psikologi penyuluh, organisasi penyuluh dan lingkungan kerja penyuluh berpengaruh terhadap kinerja penyuluh pertanian. Faktor-faktor yang berpengaruh positif signifikan terhadap tingkat kinerja penyuluh yaitu: Faktor individu (pengalaman penyuluh), faktor psikologi (persepsi penyuluh pertanian terhadap profesi penyuluh pertanian, sikap dan motivasi penyuluh pertanian), faktor organisasi (imbalan penyuluh pertanian) dan faktor lingkungan kerja (jumlah petani binaan dan interaksi penyuluh dengan petani binaan) sedangkan yang berpengaruh negatif signifiikan yaitu luas wilayah penyuluh pertanian. Penelitian ini menemukan model pemberdayaan untuk meningkatkan kinerja penyuluh yaitu dengan memperhatikan faktor individu penyuluh, psikologi, organisasi dan juga faktor lingkungan kerja penyuluh pertanian.
\end{abstract}

Kata kunci: Kinerja penyuluh pertanian, individu, psikologi, organisasi, lingkungan kerja

\section{Pendahuluan}

Dalam rangka menjamin ketersediaan pangan secara kontinu dan menghadapi era perdagangan bebas serta masyarakat ekonomi ASEAN (MEA), Pemerintah telah menetapkan target pembangunan pertanian, khusus untuk tahun 2016 telah ditetapkan sasaran produksi tujuh komoditas unggulan, yaitu: padi
76,2 juta ton, jagung 21,4 juta ton, kedelai 1,8 juta ton, tebu 3,27 juta ton, aneka cabai 1,1 juta ton, bawang merah 1,17 juta ton, serta daging sapi dan kerbau 588,6 juta ton. Berkaitan dengan pencapaian tersebut, Badan Penyuluhan dan Pengembangan Sumberdaya Manusia Pertanian (BPPSDM) berkewajiban mendukung tercapainya sasaran tersebut melalui peningkatan kinerja dan efektivitas penyuluhan. 
Dari data laporan kinerja BPPSDM tahun 2014 menunjukan bahwa sasaraan kinerja ketenagaan penyuluhaan yang belum mencapai hasil $100 \%$ memberikan dampak pada sasaran kemandirian kelembagaan petani dan kapasitas kelembagaan bidang SDM penyuluh yang belum maksimal, oleh karena itu, perlu adanya peningkatan kinerja penyuluh pertanian di semua daerah. Salah satu daerah yang perlu meningkatkan kinerja penyuluh pertaniannya adalah Kabupaeten Boyolali. Dari data Badan Ketahanan Pangan dan Pelaksanaan Penyuluhan Kabupaten Boyolali diperoleh bahwa kinerja penyuluh pertanian di tahun 2015 menunjukan Nilai Prestasi Kerja (NPK) rata-rata 83 artinya baik namun belum mencapai Nilai Prestasi Kerja (NPK) yang diharapkan yaitu 91 sampai 100. Dari data kinerja penyuluh pertanian dirincikan diperoleh bahwa ada 6 tugas pokok yang belum dilaksanakan secara maksimal dengan ratarata nilai cukup (3) dari target nilai sangat baik (5). Menurut Sulton dalam Lubis (2014) kinerja penyuluh pertanian cenderung semakin memburuk dikarenakan kendala yang dihadapi oleh penyuluhan pertanian dalam era otonomi daerah antara lain meliputi dan merupakan akibat dari: (1) Adanya perbedaan pandangan antara pemerintah daerah dan para anggota DPRD dalam memahami penyuluhan pertanian dan peranannya dalam pembangunan pertanian. (2). Kecilnya alokasi anggaran pemerintah daerah untuk kegiatan penyuluhan pertanian. (3) Ketersediaan dan dukungan informasi pertanian (teknologi, harga pasar, kesempatan berusaha tani, dan lain-lain), yang ada di Balai Penyuluhan Pertanian (BPP) sangat terbatas. (4). Semakin merosotnya kemampuan manajerial penyuluh. Akibatnya, frekuensi penyelenggaraan penyuluhan menjadi rendah.

Dari kendala-kendala yang dihadapi penyuluh pertanian di atas perlu adanya suatu pemberdayaan dari pemerintah agar meningkatkan hasil kerja dari penyuluh pertanian. Menurut Sedarmayanti (2007) pemberdayaan sumber daya manusia adalah suatu proses kegiatan usaha untuk lebih memberdayakan "daya manusia" melalui perubahan dan pengembangan manusia itu sendiri, berupa kemampuan, kepercayaan, wewenang, dan tanggung jawab dalam rangka pelaksanaan kegiatan-kegiatan organisasi untuk meningkatkan kinerja sebagaimana diharapkan. Pemberdayaan penyuluh pertanian menjadi sesuatu hal yang penting, karena di dalam menghadapi era persaingan dan pelayanan, setiap organisasi membutuhkan pekerja yang cepat tanggap dan mandiri sehingga organisasi mempunyai keunggulan kompetitif melalui sumber daya manusianya yang dimilikinya. Teori pemberdayaan masyarakat menurut Mardikanto. Dkk., (2014) pemberdayaan masyarakat dimaknai sebagai proses pengembangan kapasitas, baik kapasitas individu, etnis dan jejaring (system) yang meliputi aspek-aspek: penguatan kapasitas manusia, kapasitas usaha, kapasitas lingkungan, dan kapasitas kelembagaan.

Dalam memberdayakan penyuluh maka perlu memperhatikan kapasitas manusianya, kapasitas usaha yang perlu digunakan untuk meningkatkan pendapatan yang dimilikinya, mampu memperhatikan kapasitas lingkungan kerja yang dimiliki dan mampu memperhatikan kapasitas kelembagaan penyuluh tersebut. Dengan memberdayakan penyuluh maka dengan sendirinya akan mampu meningkatkan usaha kerja penyuluh tersebut yang berakhir pada peningkatan kinerja kerjanya. Untuk memberdayakan penyuluh pertanian maka perlu diketahui faktor-faktor apa saja yang mampu mempengaruhi kinerja penyuluh tersebut sehingga pada proses pemberdayaan penyuluh perlu memperhatikan faktor-faktor yang berpengaruh tersebut. Oleh Karena itu dalam penelitian ini akan mengkaji tentang "Model Pemberdayaan Untuk Meningkatkan Kinerja Penyuluh Pertanian di Kabupaten Boyolali Propinsi Jawa Tengah".

Penelitian ini bertujuan untuk: (1) mengetahui tingkat kinerja (performance) penyuluh pertanian di Kabupaten Boyolali. (2) menganalisis pengaruh faktor individu penyuluh terhadap kinerja penyuluh pertanian di Kabupaten Boyolali dalam melaksanakan tugas pokoknya. (3) menganalisis pengaruh faktor psikologi penyuluh terhadap kinerja penyuluh pertanian di Kabupaten Boyolali dalam melaksanakan tugas pokoknya. (4) menganalisis pengaruh faktor organisasi penyuluh terhadap kinerja penyuluh pertanian di Kabupaten Boyolali dalam melaksanakan tugas pokoknya. (5) menganalisis pengaruh faktor lingkungan kerja penyuluh terhadap kinerja penyuluh pertanian di Kabupaten Boyolali dalam melaksanakan tugas pokoknya. (6) menganalisis pengaruh secara simultan faktor-faktor yang mempengaruhi kinerja penyuluh pertanian di Kabupaten Boyolali dalam melaksanakan tugas pokoknya. (7) menemukan model pemberdayaan untuk meningkatkan kinerja penyuluh pertanian yang sesuai di Kabupaten Boyolali

Menurut Gibson dkk (2005), secara teoritis ada 
tiga kelompok variabel yang mempengaruhi perilaku kerja dan kinerja, yaitu: variabel individu, variabel organisasi dan variabel psikologis. Ketiga kelompok variabel tersebut mempengaruhi kelompok kerja yang pada akhirnya memengaruhi kinerja personel. Perilaku yang berhubungan dengan kinerja adalah yang berkaitan dengan tugas-tugas pekerjaan yang harus diselesaikan untuk mencapai sasaran suatu jabatan atau tugas, selain dari ketiga faktor diatas maka dalam penelitian ini akan menambahkan salah satu faktor lagi yaitu faktor lingkungan kerja dimana berdasarkan pendapat Zainun (1989:51) dalam Gordon (1994) dan Jones (2002:92) menyatakan bahwa lingkungan luar atau masalah lingkungan menyebabkan terjadinya kinerja yang buruk. Hal inilah yang menjadi pokok pikiran untuk merumuskan model dalam penelitian ini

Dalam penelitian ini dilakukan pengkajian terhadap tingkat kinerja (Y) dan dilakukan analisis terhadap alasan atau faktor-faktor yang mempengaruhi kinerja penyuluh pertanian yang meliputi faktor individu penyuluh pertanian $\left(\mathrm{X}_{1}\right)$, faktor psikologi penyuluh pertanian $\left(\mathrm{X}_{2}\right)$ dan faktor organisasi $\left(\mathrm{X}_{3}\right)$ dan faktor lingkungan kerja $\left(\mathrm{X}_{4}\right)$.

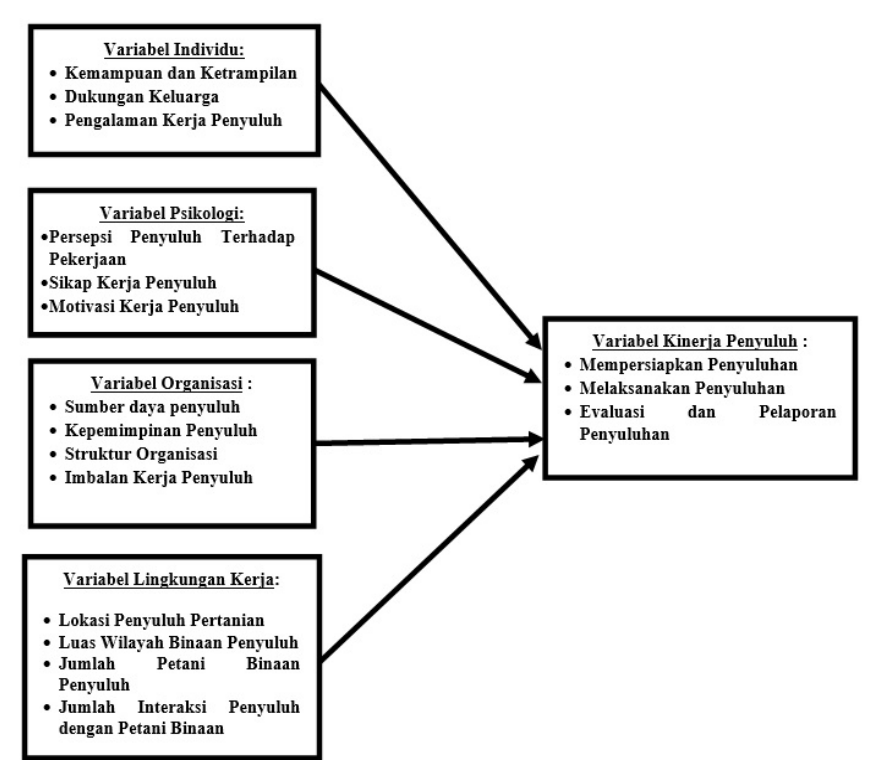

Gambar 1. Kerangka Pemikiran Penelitian Model Pemberdayaan untuk Meningkatkan Kinerja Penyuluh Pertanian di Kabupaten Boyolali Propinsi Jawa Tengah

\section{Metode Penelitian}

Jenis penelitian yang digunakan dalam penelitian ini adalah survei analitik eksplanatori dengan menggunakan rancangan cross sectional. Daerah penelitian ditentukan secara purposive yaitu di Badan Ketahanan Pangan dan Pelaksana Penyuluhan Kabupaten Boyolali hal ini di karnakan seluruh Kecamatan di Kabupaten Boyolali sudah memiliki BP3K sehingga kegiatan penyuluhan berjalan dengan baik. Penelitian ini menggunakan teknik pengambilan sampel dengan teknik sampling jenuh, karena populasinya kurang dari 100 orang maka teknik sampling yang diambil adalah semua anggota populasi yaitu sebanyak 63 orang penyuluh PNS yang ada pada Badan Ketahanan Pangan dan Pelaksanaan Penyuluhan Kabupaten Boyolali. Penelitian ini berlangsung dari bulan September sampai Nopember 2016.

Variabel bebas dalam penelitian ini adalah faktor individu yang meliputi kemampuan dan ketrampilan, dukungan keluarga dan pengalaman penyuluh; faktor psikologis yang meliputi faktor persepsi penyuluh terhadap pekerjaannya, sikap dan motivasi dari penyuluh pertanian; faktor organisasi yang meliputi sumber daya, kepemimpinan, imbalan, struktur organisasi; faktor lingkungan kerja terdiri dari lokasi tugas penyuluh, luas wilayah penyuluh, jumlah petani binaan dan jumlah interaksi penyuluh pertanian. Variabel terikat dalam penelitian ini adalah kinerja penyuluh pertanian yang ada pada Kantor Badan Pelaksanaan Penyuluhan Pertanian, Perikanan dan Kehutanan Kabupaten Boyolali. Metode pengumpulan data melalui survei dengan menggunakan kuesioner terbuka dan kuesioner tertutup. Metode analisis data yang digunakan dalam penelitian ini adalah uji validitas dengan menggunakan product moments pearson, uji reliabilitas dengan melihat koefisien alpha cronbach, analisis statistik menggunakan uji asumsi klasik dan selanjutnya analisis data penelitian menggunakan analisis regresi berganda.

\section{Hasil Dan Pembahasan}

\section{Analisis Deskriptif Kinerja Penyuluh Pertanian}

Hasil analisis kinerja penyuluh pertanian meliputi: Persiapan penyuluhan, pelaksanaan penyuluhan dan evaluasi penyuluhan. Deskripsi data penelitian variabel kinerja kerja penyuluh pertanian 
tersaji pada Gambar 2 dibawah ini.

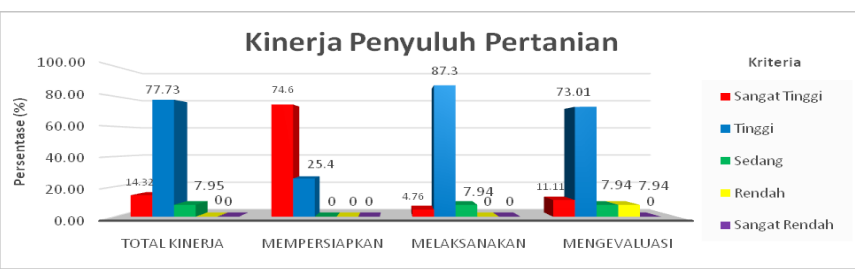

Gambar 2. Grafik Kinerja Penyuluh Pertanian

Gambar 2 menunjukan bahwa kinerja penyuluh dalam mempersiapkan, melaksanakan dan mengevaluasi penyuluhan berada pada kriteria tinggi yaitu sebanyak 77,73\%. Hal ini ditunjukan pada proses persiapan penyuluhan sebesar $74,60 \%$, proses pelaksanaan penyuluhan sebesar $87,30 \%$ dan pada proses evaluasi dan pelaporan kegiatan penyuluhan sebesar 73,01\%.

Analisis Faktor Individu, Psikologi, Organisasi dan Lingkungan Kerja terhadap Kinerja Penyuluh Pertanian

Hasil analisis kinerja penyuluh pertanian secara simultan yang di pengaruhi oleh faktor individu, psikologi, organisasi dan lingkungan kerja penyuluh terhadap kinerja penyuluh pertanian disajikan dalam Tabel 1.

Tabel 1. Hasil Uji Pengaruh Secara Simultan FaktorFaktor Yang Mempengaruhi Kinerja Penyuluh Pertanian di Kabupaten Boyolali

\begin{tabular}{lrrr}
\hline \multicolumn{1}{c}{ Model } & $\begin{array}{c}\text { Jumlah } \\
\text { Kuadrat }\end{array}$ & f hitung & Signifikan \\
\hline 1 Regresi & 1488.837 & 1355.441 & $.000^{\mathrm{b}}$ \\
Residual & 3.766 & & \\
Total & 1492.603 & & \\
& & & \\
\hline
\end{tabular}

Nilai signifikan 0,05

Berdasarkan Tabel 1 maka dapat disimpulkan bahwa $\mathrm{F}_{\text {hitung }}>\mathrm{F}_{\text {tabel }} \quad(1355,441>2,01)$, maka Ho ditolak, artinya bahwa Kemampuan dan Ketrampilan, Dukungan Keluarga, Pengalaman Penyuluh Pertanian, Persepsi Penyuluh terhadap profesinya, Sikap Penyuluh, Motivasi Penyuluh, Sumber Daya, Kepemimpinan, Struktur Organisasi Penyuluh,
Imbalan Kerja Penyuluh, Lokasi Tugas Penyuluh, Luas Wilayah Binaan Penyuluh Pertanian, Jumlah Petani Binaan dan Jumlah Interaksi secara bersamasama berpengaruh terhadap kinerja penyuluh pertanian di Kabupaten Boyolali.

\section{Analisis Faktor-Faktor Yang Berpengaruh terhadap Kinerja Penyuluh Pertanian}

Faktor-faktor yang di duga menunjukan pengaruh terhadap kinerja penyuluh pertanian meliputi faktor individu, psikologi, organisasi dan lingkungan kerja. Hasil analisis faktor-faktor yang mempengaruhi kinerja penyuluh pertanian secara parsial di kaji dalam Tabel 2.

Dari hasil analisis pada Tabel 2 menunjukan bahwa terdapat 8 faktor yang berpengaruh terhadap kinerja penyuluh pertanian yaitu pengalaman kerja penyuluh pertanian, persepsi penyuluh terhadap pekerjaannya, sikap penyuluh pertanian, motivasi penyuluh, imbalan kerja, luas wilayah binaan, jumlah petani binaan dan jumlah interaksi penyuluh dengan petani binaan sedangkan 6 faktornya tidak berpengaruh pada kinerja penyuluh pertanian yaitu kemampuan dan ketrampilan penyuluh, dukungan keluarga, sumber daya penyuluh, kepemimpinan, struktur organisasi penyuluh dan lokasi tugas penyuluh pertanian.

\section{Pengalaman Kerja Penyuluh Pertanian}

Dalam penelitian ini pengalaman kerja penyuluh pertanian berpengaruh terhadap kinerja penyuluh pertanian di Kabupaten Boyolali. Hal ini diduga disebabkan karena rata-rata penyuluh pertanian yang ada di Kabupaten Boyolali memiliki masa kerja diatas 20 tahun dengan jumlah mengikuti pelatihan dan kursus sebanyak 3 sampai 4 kali yaitu rata-rata mengikuti diklat dasar-dasar penyuluhan, kursus budidaya padi, jagung dan diklat budidaya sapi potong. Semakin lama seorang penyuluh bekerja pada bidang penyuluhan pertanian maka penyuluh tersebut akan semakin tahu dan semakin terampil melakukan persiapan penyuluhan, melaksanakan penyuluhan dan melakukan evaluasi sehingga akan semakin meningkatnya hasil kerja yang akan dihasilkan yang akan berdanpak pada kinerja yang dihasilkan. Menurut Budhyani (2008) lamanya seorang bekerja pada pekerjaan yang sama atau pada pekerjaan yang sejenis akan mengakibatkan lebih tahu dan lebih terampil dalam 
Tabel 2. Analisis Faktor-faktor yang Mempengaruhi Kinerja Penyuluh Pertanian di Kabupaten Boyolali

\begin{tabular}{lrrrl}
\hline \multicolumn{1}{c}{ Uraian } & $\boldsymbol{\beta}$ & $\mathbf{t}$ hitung & Sign & Keterangan \\
\hline (Konstan) & 1.209 & 0.161 & 0.873 & \\
Kemampuan dan Ketrampilan (X1.1) & 0.037 & 0.304 & 0.763 & Tidak signifikan \\
Dukungan Keluarga (X1.2) & 0.120 & 1.275 & 0.208 & Tidak Signifikan \\
Pengalaman (X1.3) & 0.314 & 2.091 & 0.042 & Signifikan \\
Persepsi Penyuluh (X2.1) & 0.322 & 2.846 & 0.006 & Sangat Signifikan \\
Sikap Penyuluh (X2.2) & 0.328 & 4.567 & 0.000 & Sangat signifikan \\
Motivasi (X2.3) & 0.332 & 2.747 & 0.008 & Sangat Signifikan \\
Sumber Daya (X3.1) & 0.245 & 1.911 & 0.062 & Tidak signifikan \\
Kepemimpinan (X3.2) & 0.150 & 1.195 & 0.238 & Tidak signifikan \\
Struktur Penyuluh (X3.3) & 0.001 & 0.015 & 0.988 & Tidak signifikan \\
Imbalan Kerja (X3.4) & 0.338 & 4.068 & 0.000 & Sangat Signifikan \\
Lokasi Tugas Penyuluh (X4.1) & -0.133 & -1.768 & 0.083 & Tidak Signifikan \\
Luas Wilayah (X4.2) & -0.227 & -2.888 & 0.006 & Sangat Signifikan \\
Jumlah Petani Binaan (X4.3) & 0.525 & 4.413 & 0.000 & Sangat signifikan \\
Jumlah Interaksi (X4.4) & 0.522 & 6.272 & 0.000 & Sangat signifikan \\
\hline
\end{tabular}

$\mathrm{T}_{\text {tabel }} \quad: \mathbf{2 , 0 1}$

melaksanakan pekerjaanya. Pengalaman kerja tidak hanya dinilai dari lamanya seorang pada suatu bidang pekerjaan, akan tetapi dapat dilihat dengan pelatihan atau kursus yang diikutinya. Pelatihan atau kursus yang pernah diikuti penyuluh pertanian di Kabupaten Boyolali berkaitan erat dengan bidang penyuluhan sehingga pengalaman yang dimiliki dapat membantu untuk meningkatkan kinerja yang dihasilkan. Hasil penelitian ini sejalan dengan penelitian Yuniarh (2011) yang menyatakan bahwa dengan proses pelatihan yang baik akan mampu meningkatkan kinerja penyuluh pertanian. Penelitian ini mendukung penelitian dari Situmorang (2003) yang menyatakan bahwa pelatihan sangat berpengaruh positif dan signifikan terhadap prestasi kerja karyawan.

\section{Persepsi Penyuluh Pertanian terhadap Pekerjaannya}

Tabel 2 menunjukan bahwa ada pengaruh sangat signifikan dari persepsi penyuluh terhadap profesi penyuluh pertanian. Hal ini diartikan bahwa penyuluh menilai sangat baik terhadap profesi kerja penyuluh, dengan penilaian yang baik ini berdampak pada ada peningkatan kinerja yang dihasilkan. Hal ini menunjukan bahwa semakin positif seorang penyuluh menilai profesinya maka akan berdampak pada peningkatan semangat bekerja pada instansi tersebut yang akan berdampak pada disiplin kerja yang tinggi dan menghasilkan hasil yang baik dan berakibat pada adanya peningkatan kerja yang di capai. Dari hasil penelitian menunjukan bahwa 74,44 persen penyuluh memiliki pandangan bahwa bekerja sebagai penyuluh merupakan minat dan pangilan jiwa sehingga memberikan rasa nyaman untuk tetap bekerja sebagai penyuluh, selain itu juga sebagian penyuluh menyatakan bahwa bekerja sebagai seorang penyuluh itu membanggakan dan mulia dimana membantu petani untuk bisa memberdayakan kehidupan mereka sendiri. Akibat dari penilaian penyuluh ini memberikan dorongan dari dalam diri penyuluh untuk lebih giat bekerja sebagai penyuluh yang berdampak pada pencapaian hasil yang dicapai.

Sikap Penyuluh Pertanian

Dalam penelitian ini menunjukan bahwa ada pengaruh sangat signifikan antara sikap penyuluh pertanian terhadap kinerja penyuluh pertanian. Hal ini diduga disebabkan karena rata-rata 69,72 persen penyuluh memberikan pandangan bahwa seorang penyuluh harus mampu meningkatkan pengetahuannya agar sukses dalam menyelesaikan tugas pokoknya, selain itu juga rata-rata penyuluh pertanian di Kabupaten Boyolali memiliki sikap untuk menerima hal-hal baru yang berkaitan dengan peningkatan pelaksanaan tugas pokoknya sehingga 
dengan penambahan pengetahuan tentang informasi yang baru akan memperkaya pengetahuan dari penyuluh yang ada sehingga membantu penyuluh untuk menyelesaikan masalah-masalah yang dihadainya dalam melaksanakan tugas pokoknya. Hasil penelitian ini sejalan dengan penelitian dari Margaretha dan Natalia (2012) yang menyimpulkan bahwa sikap kerja karyawan berpengaruh signifikan pada kinerja karyawan tersebut. hal ini ditunjukan dengan kepuasan kerja, komitmen organisasi, dan keterlibatan kerja yang berpengaruh positif pada kinerja yang dihasilkan. Selanjutnya penelitian ini mendukung penelitian Manggarsari (2015) yang menyimpulkan bahwa sikap kerja secara parsial berpengaruh positif terhadap kinerja karyawan, hal ini berarti bahwa semakin baik sikap kerja yang dimiliki oleh karyawan maka diharapkan kinerja karyawan akan semakin meningkat. Fenomena ini membuktikan bahwa pentingnya masalah sikap sering dikaitkan dengan perilaku atau perbuatan manusia dalam kehidupan sehari-hari. Sikap yang ada pada diri seseorang akan memberikan warna atau corak pada perilaku atau perbuatan orang yang bersangkutan. Selanjutnya dengan adanya sikap kerja karyawan yang baik terhadap perusahaan, maka akan mendorong karyawan untuk bekerja lebih baik lagi (Dongoran,2006).

\section{Motivasi Penyuluh Pertanian}

Berdasarkan Tabel 2 diatas menunjukan bahwa motivasi memberikan pengaruh positif dan sangat signifikan terhadap kinerja penyuluh pertanian. Pengaruh motivasi yang ditunjukan oleh penyuluh di Kabupaten Boyolali diduga dilatar belakangi oleh adanya dorongan untuk memenuhi kebutuhan dasar yang ditunjukan sebesar 76,56 persen penyuluh yang memilih untuk memenuhi kebutuhan dasar dan juga dorongan yang tinggi untuk memenuhi kebutuhan prestasi kerja yaitu sebesar 75,26 persen penyuluh ingin untuk meningkatkan prestasi kerja. Hal ini sejalan dengan pendapat dari Gibson et al (2012) menyatakan bahwa motivasi sebagai suatu dorongan yang timbul padaatau didalamseorang individu yang menggerakkan dan mengarahkan perilaku. Oleh karena itu, motivasi dapat berarti suatu kondisi yang mendorong atau menjadi sebab seseorang melakukan suatu perbuatan / kegiatan yang berlangsung secara wajar. Hasil penelitian ini mendukung penelitian dari Jide Ibietan (2010) dalam penelitianya tentang menghubungkan teori Motivasi dalam praktek manajemen dan dari hasil penelitiannya merekomendasikan bahwa manajer harus peka terhadap kebutuhan karyawan sehingga dengan terpenuhinya kebutuhan maka karyawan bisa mencapai kinerjanya yang baik yang berpengaruh terhadap pencapaian tujuan organisasi. Selain itu juga hasil penelitian ini sepadan dengan hasil penelitian yang dilakukan oleh Kusminarti (2013) yang menemukan bahwa motivasi kerja berpengaruh signifikan terhadap kinerja perawat, artinya semakin tinggi motivasi kerja seseorang, maka secara otomatis mempengaruhi tingkat kinerjanya. Sartono (2008) hasil penelitian ditemukan variabel profesional, motivasi dan lingkungan berpengaruh positif dan signifikan terhadap kinerja organisasi. Endang Dwiningsih (2008) dan Hariyanti dan Primawestri (2009) membuktikan ada pengaruh motivasi kerja terhadap kinerja perawat. Mayasari (2008) menemukan motivasi kerja berpengaruh terhadap kinerja pegawai Dinas Pendidikan dan Kebudayaan Kabupaten Ngawi.

\section{Imbalan Penyuluh Pertanian}

Tabel 2 menunjukan bahwa ada pengaruh sangat signifikan dari imbalan terhadap kinerja penyuluh. Hal ini diduga disebabkan karena rata rata 83,13 persen penyuluh pertanian menyatakan bahwa gaji yang diterima sangat mendukung kinerjanya, dengan imbalan yang cukup akan memudahkan seorang penyuluh untuk melaksanakan tugasnya, selain memudahkan dalam bekerja tentunya membantu memenuhi kebutuhan dari penyuluh sehingga semakin sejahtera, semakin sejahteranya seorang penyuluh akan memotivasi penyuluh tersebut untuk lebih semangat bekerja yang berakhir pada adanya peningkatan kerja yang dihasilkan sehingga akan berdanpak pada peningkatan kinerja yang dicapai. Gibson., dkk (2005) menyatakan bahwa imbalan ekstinsik dan intrinsik dapat digunakan untuk memotivasi seorang untuk meningkatkan prestasi kerjanya. Semakin tinggi seorang bawahan puas terhadap imbalan yang diterima maka akan meningkatkan motivasi prestasi dalam diri seorang bawahan untuk giat bekerja lebih baik yang akan berdampak pada hasil kinerja yang tinggi.

\section{Luas Wilayah Binaan Penyuluh Pertanian}

Tabel 2 menunjukan bahwa ada pengaruh negatif sangat signifikan dari luas wilayah binaan 
penyuluh pertanian terhadap kinerja penyuluh pertanian di Kabupaten Boyolali. Hal ini disebabkan karena semakin luas wilayah kerja penyuluh pertanian, maka semakin sulit baginya untuk melakukan penyuluhan, karena akan membutuhkan waktu lama dan biaya operasional yang tinggi untuk mencapai wilayah kerjanya. Hal ini berdampak pada terlambatnya informasi pertanian yang akan disampaikan pada petani, sehingga keinginan petani untuk memperoleh informasi pertanian tidak segera terwujud. Dengan demikian luas wilayah kerja akan berpengaruh pada kinerja penyuluhan pertanian.

\section{Jumlah Petani Binaan Penyuluh Pertanian}

Tabel 2 menunjukan bahwa jumlah petani binaan penyuluh pertanian berpengaruh terhadap kinerja penyuluh pertanian. Hal ini menunjukan bahwa rata rata 94,55 persen penyuluh pertanian memiliki jumlah kelompok tani binaan sebanyak 6 sampai 8 kelompok tani dengan rata-rata sebanyak 92,99 persen penyuluh memiliki $188-250$ petani binaan. Jumlah kelompok tani dan jumlah petani binaan yang ada menurut penyuluh masih bisa dijangkau untuk melaksanakan pendampingan dan melaksanakan penyuluhan, hal ini disebabkan karena kemungkinan fasilitas yang diberikan kepada penyuluh sudah memadai seperti sepeda motor bagi setiap penyuluh sehingga memudahkan penyuluh untuk lebih cepat berkunjung ke semua petani binaan yang ada sehingga dengan jumlah kelompok tani dan jumlah petani binaan yang ada masih bisa dijangkau oleh penyuluh dengan baik sehingga tidak berpengaruh pada kinerjanya. Hal ini didukung oleh rata-rata sebanyak 93.69 penyuluh menyatakan bahwa jumlah petani binaan yang ada diwilayah binaanya masih mendukung kinerjanya.

\section{Jumlah Interaksi Penyuluh Pertanian}

Tabel 2 menunjukan adanya pengaruh sangat signifikan dari jumlah interaksi penyuluh pertanian terhadap kinerja penyuluh pertanian. Hal ini diduga disebabkan karena rata-rata 88,96 persen penyuluh memberikan pandangan bahwa dengan kunjungan atau tatap muka dengan petani binaan maka penyuluh akan mengetahui kebutuhan dari petani binaan sehingga akan membantu penyuluh untuk mencari solusi yang tepat untuk menyelesaikan kebutuhan dan permasalahan yang petani binaan hadapai. Hal ini juga diperkuat dengan rata-rata 86.27 persen penyuluh memberikan pandangan bahwa seorang penyuluh harus mampu berinteraksi dengan petani binaan, sehingga penyuluh menyadari bahwa bukan seberapa banyak interaksi penyuluh dengan petani namun keharusan bagi penyuluh untuk selalu mendampingi petani binaanya.

\section{Kemampuan dan Ketrampilan Penyuluh Pertanian}

Kemampuan dan ketrampilan penyuluh pertanian menunjukan tidak ada pengaruh signifikan terhadap kinerja penyuluh pertanian yang ada di Kabupaten Boyolali. Hal ini diduga disebabkan karena rata-rata penyuluh yang ada di Kabupaten Boyolali memiliki kemampuan dan ketrampilan yang dominan pada aspek kemampuan fisik dan stamina yang tinggi yaitu sebesar 80,98 persen dibandingkan dengan aspek kemampuan lainya baik kemampuan penyuluh dalam menguasai materi dan metode penyuluhan. Dalam penelitian ini rata-rata penyuluh pertanian yang ada di Kabupaten Boyolali memiliki kemapuan fisik dan stamina yang tinggi dibandingkan dengan kemampuan intelektual dan ketampilan kerja sehingga tidak ada pengaruh yang besar terhadap kinerja kerja penyuluh. Badeni(2014:16) yang menyatakan bahwakemampuan intelektual lebih besar memainkan peranan pada pekerja-pekerja yang rumit yang menuntut berbagai persyaratan pemrosesan informasi dibandingkan dengan kemampuan fisik lebih banyak diperlukan pada aktivitas atau tugas-tugas yang menuntut stamina, kecekatan, kekuatan dan ketrampilan.

Selain dari aspek kemampuan diatas diduga pula bahwa belum adanya atau belum optimalnya kegiatan analisis pekerjaaan yang dijalankan oleh instansi penyuluhan terhadap penyuluh pertanian sehingga belum diketahui kendala-kedala dari setia individu penyuluh terhadap kemampuan yang dimilikinya sehingga berdanpak pada tidak adanya pengaruh dari kemampuan dan ketrampilan kerja terhadap kinerja yang dihasilkan. Menurut Gibson., dkk (2012) analisis pekerjaan adalah suatu proses perumusan dan mempelajari suatu pekerjaan menurut tugas atau perilaku dan merincikan tanggung jawab, persyaratan pendidikan dan kebutuhan pelatihan. Badeni (2014:16) mengatakan bahwa tingkat kemampuan orang berbeda-beda. Ada sejumlah orang yang sangat pintar menulis, cepat memahami sesuatu, mampu melihat penyebab suatu masalah, terampil 
mengerjakan pekerjaanya, mampu berkomonikasi dengan baik dengan orang lain dan lain-lain. Sementara sejumlah orang yang lain memiliki tingkat kemampuan yang terbatas, umpamanya kemampuan cepat memahami orang lain dan kemampuan bekerja sama dengan orang lain. Kemampuan-kemampuan yang berbeda-beda inilah yang perlu diketahui oleh instansi sehingga bisa mencocokan kemampuan dan ketrampilan yang dimiliki oleh setiap penyuluh dengan persyaratan pekerjaan. Hasil penelitian ini sejalan dengan penelitian dari Annisa (2016), yang menyatakan bahwa tidak ada pengaruh antara kemampuan kerja terhadap kinerja karyawan pada PT Makmur Sejahtera Wisesa Tanjung Tabalong-Kalimantan Selatan hal itu disebabkan karena belum adanya system penilaan dari faktor kemampuan kerja terhadap faktor kinerja karyawan yang ada pada PT Makmur Sejahtera Wisesa Tanjung Tabalong-Kalimantan Selatan sehingga belum diketahui kemampuan dari masing-masing individu sehingga proses penempatan karyawan pada pekerjaan tidak sesuai dengan kemampuan yang dimiliki.

\section{Dukungan Keluarga Penyuluh Pertanian}

Tabel 2 menunjukan bahwa tidak ada pengaruh antara dukungan keluarga terhadap kinerja penyuluh. Hal ini disebabkan karena rata-rata dukungan keluarga yang diberikan keluarga terhadap penyuluh paling tinggi hanya pada aspek dukungan rasa nyaman dari keluarga sebesar 77 persen seperti dukungan keluarga berupa selalu memberikan ketenangan dirumah saat seorang penyuluh menyelesaikan tugas kantor yang belum diselesaikan dikantor sedangkan dukungan berupa perhatian dan penghargaan yang diberikan keluarga terhadap seorang penyuluh relatif lebih rendah sehingga tidak berdanpak terhadap kinerja penyuluh tersebut. Selain hal diatas diduga disebabkan karena responden yang dipilih dalam penelitian ini adalah penyuluh PNS dimana pada waktu menjadi seorang PNS harus mematuhi setiap aturan-aturan yang mengikat dan dituntut untuk bekerja dengan penuh pengabdian sehingga seorang penyuluh walaupun tanpa atau adanya dukungan keluarga banginya, tetap melakukan pekerjaan sesuai dengan tugas yang diberikan kepadanya dengan penuh tanggung jawab yang tinggi. Hasil penelitian ini sejalan dengan temuan dari Linandar (2009) yang menyatakan bahwa dukungan keluarga tidak berpengaruh pada hasil kerja untuk meningkatkan karier yang dicapai oleh pegawai dalam hal ini pegawai wanita PNS yang ada pada kantor badan pemberdayaan masyarakat dan keluarga berencana Kota Bogor.

\section{Sumberdaya Penyuluh Pertanian}

Tabel 2 menunjukan bahwa tidak terdapat pengaruh signifikan dari sumber daya penyuluh pertanian terhadap kinerja penyuluh pertanian. Hal ini diduga disebakan karena rata-rata sebanyak 78,40 persen responden beranggapan bahwa mereka memiliki kemampuan akademik yang sesuai dengan pekerjaan yang dibebankan kepada mereka sehingga mereka mampu untuk mengatasi setiap permasalahan dalam pekerjaan mereka, selain itu juga sebanyak 67,83 persen responden beranggapan bahwa setiap penyuluh yang ada memiliki teknik untuk meningkatkan kemampuan yang dimiliki sehingga mampu mengatasi masalah yang dihadapi, walaupun jumlah penyuluh yang ada di Kabupaten Boyolali belum sesuai satu desa satu penyuluh pertanian namun karena penyuluh yang ada memilikin latar belakang pendidikan yang sesuai dan pengalama yang tinggi sehingga mampu memecahkan setiap masalah yang dihadapi di daerah binaanya. Hal inilah yang berdanpak pada kinerja yang dihasilkan, walaupun dengan sumberdaya penyuluh yang masih belum sesuai dengan satu desa satu penyuluh pertanian.

\section{Kepemimpinan Penyuluh Pertanian}

Tabel 2 menunjukan tidak ada pengaruh kepemimpinan penyuluh pertanian terhadap kinerja penyuluh pertanian. Hal ini diduga disebabkan karena pemimpin belum sepenuhnya optimal dalam membina komonikasi yang baik dengan bawahanya dimana target yang diharapkan 100 persen pemimpin harus selalu membina komonikasi dalam hal ini pemimpin harus selalu mengarahkan dan menjelaskan perintah ataupun tugas yang diberikan kepada penyuluh dengan baik namun pada kenyataanya pemimpin hanya mampu membina kominikasi dengan bawahanya sebesar 76,72 persen saja dan belum sepenuhnya optimal memotivasi penyuluh pertanian yang ada untuk mampu bekerja dengan baik. Hal ini diduga disebabkan karena tugas utama penyuluh adalah melakukan pendampingan pada petani binaan, sehingga waktu kerja yang digunakan oleh penyuluh adalah selalu berinteraksi dengan petani binaan sehingga waktu untuk bertemu atau berinteraksi dengan atasan lebih sedikit akibatnya 
berdanpak pada belum optimalnya dukungan yang diberikan atasan terhadap penyuluh pertanian. Gibson., dkk (2005) mengatakan bahwa keefektifan kepemimpinan tergantung pada kecocokan antara pemimpin, pengikut dan situasi, selanjutnya kejelasan dan ketepatan komonikasi dari seorang pemimpin mempengaruhi perilaku dan prestasi pengikutnya. Artinya bahwa semakin cocok antara pemimpin dan penyuluh maka akan semakin efektif peranan pemimpin dalam mempengaruhi penyuluh untuk bekerja mencapai tujuan yang ingin dicapai sehingga mampu menikatkan hasil kerja penyuluh tersebut.

\section{Struktur Organisasi Penyuluh Pertanian}

Tabel 2 menunjukan bahwa tidak ada pengaruh signifikan dari struktur organisasi terhadap kinerja penyuluh, artinya bahwa semakin baik struktur organisasi tidak berpengaruh pada kinerja penyuluh yang ada. Hal ini diduga disebabkan karena penyuluh yang di pilih dalam penelitian ini adalah penyuluh PNS dimana sesuai aturan PNS setiap penyuluh wajib melaksanakan tugasnya dengan baik sesuai dengan tugas pokok yang sudah di atur dalam aturan PNS sehingga walaupun strukut organisasi berubah tidak mempengaruhi tugas pokok peyuluh, dimana tugas pokok penyuluh adalah mempersiapkan kegiatan penyuluhan didaerah binaan, melaksanakan kegiatan penyuluhan dan melakukan evaluasi kegiatan penyuluhan. Dalam pembentukkan struktur kelembagaan penyuluh di tiap daerah, ada yang berdiri sendiri sebagai Badan Koordinasi Penyuluhan (Bakorluh) di tingkat Propinsi dan Badan Pelaksana Penyuluhan (Bappeluh) di tingkat Kabupaten/Kota, tapi banyak juga yang masih digabungkan dengan Badan atau Dinas lain seperti Badan Ketahanan Pangan dan Dinas Pertanian, tergantung dengan kondisi daerah, karena di era otonomi ini, kewenangan untuk membentuk Satuan Kerja Perangkat Daerah (SKPD) menjadi kewenangan pemerintah Propinsi maupun Kabupaten/Kota.

Untuk menyeragamkan kelembagaan penyuluh di daerah, kemudian pemerintah mengeluarkan Peraturan Presiden (Perpres) Nomor 154 Tahun 2014 tentang Kelembagaan Penyuluh Pertanian. Namun demikian Perpres tersebut belum sepenuhnya dapat diimplementasikan di semua daerah. Faktor kebutuhan dan kondisi serta anggaran, kemudian mejadi alasan utamanya. Meski berada dalam wadah kelembagaan yang berbeda-beda, namun tugas dan fungsi penyuluh pertanian di semua daerah tetap mengacu kepada Undang Undang Nomor 16 Tahun 2006 yaitu, sebagai pendamping dan pembina petani. Demikian juga dengan hak kepegawaian penyuluh pertanian, tetap mengacu kepada Peraturan Menteri Pertanian Nomor 35/Permentan/OT.140/7/2009 tentang Jabatan Fungsional Penyuluh Pertanian dan Angka Kreditnya. Jadi sebenarnya perbedaan bentuk lembaga penyuluhan yang ada di daerah tidak mempengaruhi hak dan kewajiban penyuluh pertanian. Hanya saja dengan adanya kelembagaan penyuluh yang berdiri sendiri, akan lebih memudahkan koordinasi dalam pelaksanaan tugas penyuluh. Namun demikian, dimanapun para penyuluh itu bernaung, tugas dan fungsi mereka tidak akan berubah, artinya tugas kepenyuluhan itu tidak semata-mata tergantung kepada lembaga yang menaunginya tapi lebih kepada peran dan fungsi mereka.

\section{Lokasi Tugas Penyuluh Pertanian}

Berdasarkan hasil analisis menunjukan bahwa tidak adanya pengaruh negatif yang signifikan lokasi tugas penyuluh pertanian terhadap kinerja penyuluh pertanian di Kabupaten Boyolali. Hal ini diduga disebakan karena rata-rata 78,92 persen penyuluh menyatakan jarak yang ditempuh penyuluh kelokasi kerja dan ke lokasi petani binaan berjarak 10 kilo meter dan kondisi jalan yang tidak ekstrim/sulit sehingga menurut penyuluh kondisi yang ada masih bisa dijangkau oleh penyuluh sehingga dengan lokasi tugas

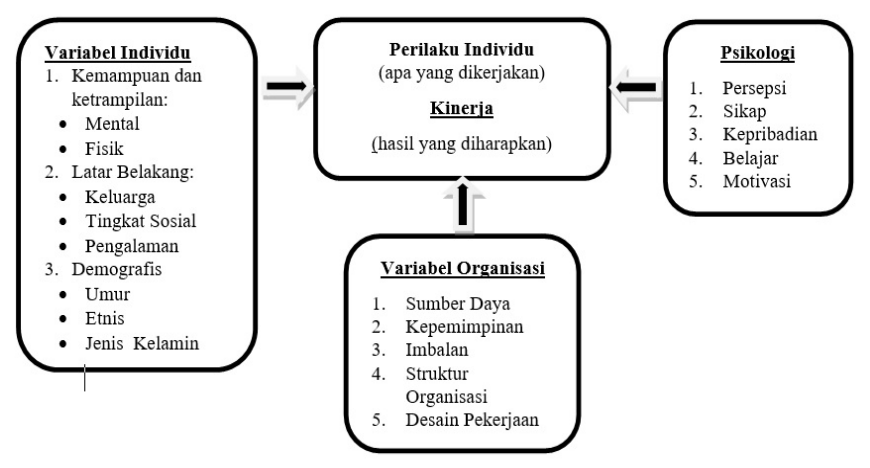

Sumber: Editing Drs. Djarkasih, MPA. Penerbit Erlangga 2005

Gambar 3. Diagram Skematis Teori Perilaku dan Kinerja dari Gibson 
yang ada sampai saat ini belum menyulitkan penyuluh untuk bekerja atau dengan kata lain lokasi tugas yang ada belum mempengaruhi kinerja kerja saat ini.

Dari pembahasan diatas dapat mendukung teori perilaku dan kinerja dari Gibson., dkk (2005) dan juga sekaligus mengkritisi penggunaan teori ini dalam bidang penyuluhan pertanian di Kabupaten Boyolali. Diagram teori perilaku dan kinerja dari Gibson., dkk (2005) digambarkan pada Gambar 3.

Dari gambar 3 diatas menunjukan bahwa terdapat 3 variabel yang mempengaruhi kinerja dari seorang individu yaitu variabel individu, variabel psikologi dan variabel organisasi. Dalam penelitian ini menggunakan ketiga variabel tersebut namun ada beberapa sub variabel yang belum digunakan dalam penelitian ini seperti demografi dimana peneliti belum mau untuk melihat perbedaan yang terdapat pada umur, etnis dan jenis kelamin dimana penyuluh yang digunakan dalam penelitian ini adalah penyuluh pertanian PNS dimana baik umur sudah ditentukan batas minimal menjadi penyuluh dan batas pensiunnya sehingga peneliti tidak melihat perbedaan yang ada pada umur, selain itu juga seperti etnis dimana penyuluh yang ada di Kabupaten Boyolali mayoritas dari Jawa sehingga tidak terdapat multietnis. Selain dari demografi, sub variabel berupa kepribadian dan belajar bisa dilihat dari sub variabel yang lain sehingga dalam penelitian ini peneliti belum menggunakannya. Dalam penelitian ini mengktitisi penggunaan teori prilaku dan kinerja dari Gibson., dkk (2005) tersebut apabila diaplikasikan pada bidang penyuluhan pertanian PNS di Kabupaten Boyolali, dimana dalam teori ini terdapat tiga variabel yang berpengaruh pada kinerja yaitu variabel individu, variabel psikologi dan variabel organisasi namun apabila ingin diaplikasikan teori ini pada bidang penyuluhan pertanian maka perlu menambahakan variabel lingkungan kerja dimana lingkungan kerja menurut Zainun (1989:51) dalam Gordon (1994) dan Jones (2002:92) menyatakan bahwa lingkungan luar atau masalah lingkungan menyebabkan terjadinya kinerja yang buruk. Sehingga dalam penelitian ini peneliti melihat variabel individu, variabel psikologi, variabel organisasi dan variabel lingkungan kerja dari penyuluh pertanian. Dari hasil analisis dan pembahasan diatas dapat disimpulkan model pemberdayaan yang tepat untuk mendukung peningkatan kerja dari penyuluh pertanian yang ada di Kabupaten Boyolali. Adapun model tersebut dapat dilihat pada gambar 4 .

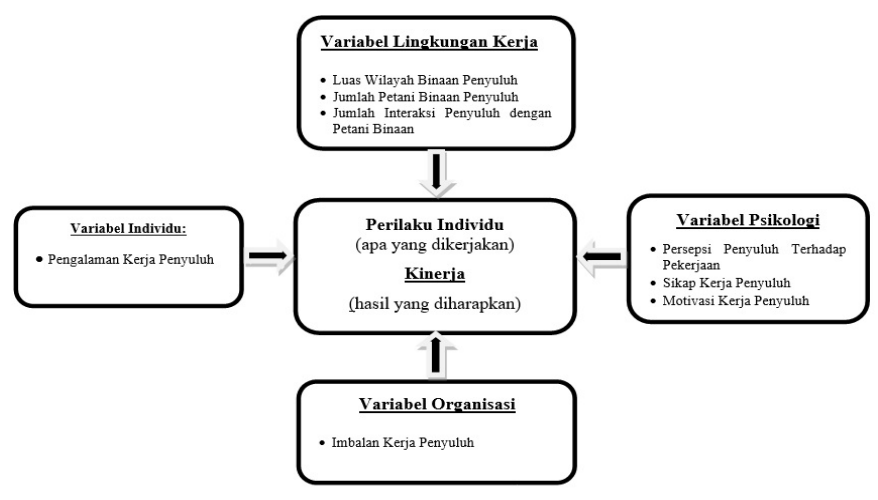

Gambar 4. Model Pemberdayaan Untuk Meningkatkan Kinerja Penyuluh Pertanian.

Model ini berkaitan erat dengan faktorfaktor yang secara signifikan berpengaruh pada kinerja penyuluh pertanian tersebut. Dimana model pemberdayaan ini diharapkan menjadi pedoman bagi para pimpinan guna menata penyuluh pertanian yang ada guna meningkatkan kinerja penyuluh kedepannya. Dari model yang terdapat pada Gambar 4, menunjukan bahwa variabel individu berupa pengalaman penyuluh sangat berpengaruh terhadap kinerja penyuluh oleh karena itu perlu adanya peningkatan pelatihan kerja bagi para penyuluh pertanian guna meningkatkan pengalaman kerja mereka. Adapun variabel psikologi menunjukan pengaruh yang sanggat signifikan terhadap kinerja penyuluh pertanian baik persepsi penyuluh terhadap pekerjaanya, sikap yang ditunjukan penyuluh terhadap pekerjaannya sangat baik sehingga mendukung kinerja kerjanya dan motivasi kerja yang ditunjukan sangat tinggi baik motivasi untuk memenuhi kebutuhan dasar dan juga motivasi untuk berprestasi. Selain itu juga variabel organisasi juga turut mempengaruhi kinerja penyuluh pertanian dimana penyuluh pertanian banyak yang menilai perlu adanya imbalan yang cukup untuk meningkatkan semangat kerja mereka yang berakibat pada adanya peningkatan kinerja. Variabel lingkungan kerja menunjukan hasil yang sangat signifikan yang ditunjukan oleh tiga faktor berupa luas wilayah kerja, jumlah petani binaan dan jumlah interaksi penyuluh dengan petani binaan.

\section{Kesimpulan}

Berdasarkan hasil Penelitian dan Pembahasan, maka dapat diambil suatu simpulan, yaitu (1). Secara 
umum tinggkat kinerja penyuluh pertanian PNS (Y) di Kabupaten Boyolali berada dalam kategori tinggi $(77.78 \%)$. Hal ini ditunjukan oleh tingginya kinerja berdasarkan pada 3 aspek yaitu: aspek persiapan penyuluhan pertanian kategori sangat tinggi $(74,60 \%)$, aspek pelaksanaan penyuluhan pertanian dengan kategori tinggi (87,30\%) dan aspek evaluasi dan pelaporan yang berada dalam kategori tinggi $(70,00 \%)$. (2). Faktor individu yang secara signifikan berpengaruh pada kinerja penyuluh pertanian adalah pada faktor pengalaman penyuluh pertanian. (3). Faktor psikologi yang secara signifikan berpengaruh pada kinerja penyuluh pertanian hal ini ditunjukan oleh tiga faktor yaitu faktor persepsi penyuluh terhadap pekerjaanya, faktor sikap penyuluh terhadap pekerjaanya dan faktor motivasi kerja dari penyuluh yang secara langsung berpengaruh sangat signifikan terhadap kinerja penyuluh pertanian. (4). Faktor Organisasi yang secara signifikan berpengaruh pada kinerja penyuluh pertanian yaitu pada faktor imbalan kerja penyuluh pertanian yang menunjukan hasil yang sangat signifikan. (5). Faktor lingkungan kerja yang secara signifikan berpengaruh pada kinerja penyuluh adalah faktor luas wilayah penyuluh, faktor jumlah petani binaan dan faktor jumlah interaksi penyuluh dengan petani binaan. (6). Secara simultan faktor individu penyuluh, faktor psikologi penyuluh, faktor organisasi penyuluh dan faktor lingkungan kerja penyuluh berpengaruh langsung terhadap kinerja penyuluh yang ditunjukan dengan nilai $\mathrm{F}_{\text {hitung }}$ sebesar 1355. (7). Dalam penelitian ini menemukan model pemberdayaan untuk meningkatkan kinerja penyuluh pertanian yaitu kinerja penyuluh tidak hanya di pengaruhi oleh faktor individu penyuluh, faktor psikologi dan faktor organisasi penyuluh, tetapi juga di pengaruhi oleh faktor lingkungan kerja. Untuk memberdayakan penyuluh pertanian di Kabupaten Boyolali maka perlu meningkatkan pengalaman kerja penyuluh dengan memperbanyak pelatihan yang ada, meningkatkan persepsi penyuluh terhadap pekerjaanya, perlu memperhatikan sikap dan juga motivasi penyuluh agar menjadi dorongan bagi penyuluh untuk bekerja sehingga tercapai hasil yang diharapkan selain itu juga agar kinerja penyuluh meningkat perlu memperhatikan imbalan kerja yang sesuai dengan beban kerja yang di berikan, perlu memperhatikan luas wilayah binaan seorang penyuluh sehingga tidak berdanpak pada banyaknya jumlah petani binaan yang di bina dan juga berdanpak pada banyaknya interaksi dengan petani binaan.

\section{Daftar Pustaka}

Annisa, C.P. 2016. Pengaruh Kemampuan Kerja Dan Motivasi Kerja Terhadap Kinerja Karyawan (Studi pada karyawan PT Makmur Sejahtera Wisesa Tanjung Tabalong - Kalimantan Selatan). [Tesis] Surakarta (ID):Universitas Muhammadiyah Surakarta

Badeni. (2014). Kepemimpinan \& Perilaku Organisasi, Edisi Kedua. Bandung: Alfabeta.

Budhyani, I.D.A.M. dan Sila, I Nyoman. 2008. Potensi Perajin Wanita Dalam Pengembangan Kerajinan Uang Kepeng Di Kawasan Pariwisata Ubud Bali. Jurnal Penelitian dan Pengembangan Sains dan Humaniora (Online). $2: 43-45$

Dongoran, Jhonson, 2006, "Pengaruh Sikap Kerja Terhadap Kinerja Pada Hotel Bintang di Jawa Tengan dan Daerah Istimewa Yogyakarta. Jurnal Akuntansi dan Manajemen,Vol XVII No.1 April Hal 79-92.

Dwiningsih Endang., 2008. Pengaruh Komunikasi, Motivasi Kerja, Lingkungan Kerja, Kemampuan Kerja, Manajemen Konflik, Dan Tingkat Kesejahteraan Terhadap Kinerja Karyawan Pada Akademi Perawatan Panti Kosala Surakarta. e-Jurnal STIE-AUB Surakarta. Vol 1, No. 1 (Maret 2008)

Gibson., dkk. 2005. Organisasi: Perilaku, Struktur dan Proses. Editing Drs. Djarkasih, MPA. Penerbit Erlangga. Hal 52.

Gibson, J.L., John M. Ivancevich, James H. Donnelly Jr., and Robert Konopaske. 2012. Organizations: Behavior, Structure, Processes, Fourteenth Edition. Published by McGraw-Hill, a business unit of The McGraw-Hill Companies, Inc., 1221 Avenue of the Americas, New York, NY, 10020. Copyright (C) 2012 by The McGraw-Hill Companies Inc. All rights reserved. Previous editions (C) 2009, 2006, and 2003.

Gordon, Thomas. 1994. Menjadi Pemimpin Efektif: Dasar untuk Manajemen Partisipatif dan Keterlibatan Karyawan. Terjemahan Alex Tri Kantjono Widodo. Jakarta: Gramedia Pustaka Utama.

Hariyanti dan Inten Primawestri, 2009, "Pengaruh Komunikasi dan Motivasi Kerja terhadap Kinerja Perawat dengan Komitmen Organisasi Sebagai 
Variabel Moderating". [Tidak dipublikasikan] Surakarta (ID): STIE AUB dan Universitas Setia Budi Surakarta.

Ibietan, J. (2010a). "The Role of Local Government in

Rural Development Issues."KnowledgeReview. Vol.20.No.2. (April).pp 30 - 36.

Jones George, J. M., G. R.. 2002. Understanding and Managing Organizational Behavior. New Jersey: Prentice Hall.

Kusminari R. 2013. Pengaruh persepsi tentang profesionalisme, Komunikasi dalam lingkungan kerja dan motivasi Kerja terhadap kinerja perawat di rumah sakit PKU Muhammadiyah Karanganyar. [Tesis] Surakarta (ID): Program Pascasarjana Universitas Muhammadiyah Surakarta.

LinandarT.N.2009.Faktor-FaktorYangMempengaruhi Karier Wanita (Studi Kasus: Badan Pemberdayaan Masyarakat dan Keluarga Berencana Kota Bogor). [Tesis] Bogor (ID): Institut Pertanian Bogor.

Laporan Tahunan Badan Ketahanan Pangan dan Pelaksanaan Penyuluhan Pertanian, Perikanan, Kehutanan Kabupaten Boyolali tahun 2015.

Lubis Rafiqah Amanda. 2014. Faktor-Faktor Yang Mempengaruhi Kinerja Penyuluh Pertanian Di Kabupaten Mandailing Natal. Pertanian, P., 2014. [Tesis] Medan (ID): Universitas Sumatera Utara.

Margaretha M dan Natalia. 2012. Pengaruh Sikap Kerja Terhadap Kinerja Karyawan Pada PT. Duta Marga Silima di Jakarta. Jurnal Manajemen dan Bisnis Vol. 2 No. 2 April 2012: 151-166

Manggarsari M.S. 2015. Pengaruh Sikap Kerja, Motivasi Kerja dan Komitmen Organisasi Terhadap Kinerja Karyawan Pada PT. Patrinsaka Gempol - Pandaan, Pasuruan. [Skripsi] Surabaya (ID): Program Studi Manajemen Fakultas Ekonomi Universitas Narotama Surabaya

Mardikanto T. 2009. Sistem Penyuluhan Pertanian. Sebelas Maret University Press. Surakarta.

Mardikanyo T., dkk (2014) Pengembangan Masyarakat (Community Development). Sebelas Maret University Press. Surakarta.

Mayasari, M. Kholila. 2008, "Hubungan Komunikasi dalam Organisasi, Kondisi Fisik Lingkungan dan Motivasi Kerja dengan Kinerja Pegawai Dinas Pendidikan dan Kebudayaan Kabupaten Ngawi”. [Skripsi] Malang (ID):Universitas Negeri Malang. Sartono. 2008, "Pengaruh Kepemimpinan, Profesional, Motivasi, Lingkungan Kerja dan Disiplin Kerja terhadap Kinerja Organisasi pada Universitas
Sebelas Maret Surakarta". [internet]. [dapat di unduh di download.portalgaruda.org/article. php?article $=90046 \& v a l=4992]$.

Sedarmayanti. 2007. Manajemen Sumber Daya Manusia Reformasi Birokrasi dan Manajemen Pegawai Negeri Sipil. Badung: Refika Aditama.

Syahyuti, 2006. 30 Konsep Penting Dalam Pembangunan Pedesaan dan Pertanian: Penjelasan tentang konsep, istilah, teori dan indikator serta variabel. Bina Rena Pariwara, Jakarta.

Situmorang S. H. 2003. Pengaruh Pelatihan dan Pengembangan serta Prestasi Kerja Terhadap Pengembangan Karir Karyawan. [Tesis] Medan (ID): Universitas Sumatra Utara. Medan. No Akses 04011740

Yuniarh Wiwik. 2011. Analisis Kinerja Penyuluh di Kabupaten Bogor. [Tesis] Surakarta (ID): Program Pascasarjana Universitas Sebelas Maret. Surakarta.

Zainun Buchari. 1989. Manajemen dan Motivasi. Jakarta : Balai Aksara. 